NBER WORKING PAPER SERIES

\title{
BANK RUNS AND BANKING POLICIES: LESSONS FOR AFRICAN POLICYMAKERS
}

\author{
Edward J. Kane \\ Tara Rice
}

Working Paper 8003

http://www.nber.org/papers/w8003

\author{
NATIONAL BUREAU OF ECONOMIC RESEARCH \\ 1050 Massachusetts Avenue \\ Cambridge, MA 02138 \\ November 2000
}

The authors are respectively James F. Cleary Professor and Doctoral Candidate in Finance at Boston College. The paper has benefitted from the research assistance of Tolga Sobaçi and from criticisms from Tonji Sobodu and an anonymous referee. The analysis draws heavily on Kane (1999a and b). The empirical work was started in summer 1998 when Tara Rice was a visiting financial economist at the Office of the Controller of the Currency (OCC). Some data were obtained from the OCC using the FitchIBCA Bankscope database. The views expressed in this paper are those of the authors and not necessarily those of the National Bureau of Economic Research.

(C) 2000 by Edward J. Kane and Tara Rice. All rights reserved. Short sections of text, not to exceed two paragraphs, may be quoted without explicit permission provided that full credit, including $\odot$ notice, is given to the source. 
Bank Runs and Banking Policies:

Lessons for African Policymakers

Edward J. Kane and Tara Rice

NBER Working Paper No. 8003

November 2000

JEL No. F3, G2, O2

\begin{abstract}
This paper documents and explains the near-permanent banking stress African countries have experienced during the last 20 years. The central hypothesis is that banking stress comes predominantly from unbooked losses and that the level of unbooked losses a banking system can accumulate depends on its information environment and on the effectiveness of government efforts to supervise and guarantee bank solvency. African depositors face high costs for mitigating the loss exposures that banks and regulators impose on them and African regulators have not been made accountable for these costs. We present evidence that over 1980-99 the average length of time an African banking system spent in crisis increased with the level of government corruption.
\end{abstract}

Edward J. Kane

Finance Department

Boston College

Chestnut Hill, MA 02467

and NBER

edward.kane@bc.edu
Tara Rice

Finance Department

Boston College

Chestnut Hill, MA 02467 
In Africa, as in most other developing regions, the predominant source of banking stress is nonperforming loans. A loan is seldom classified as nonperforming until payments due under the contract have fallen six or more months in arrears.

Individual banks experience stress when the cash flows generated by their earning assets prove insufficient to service their deposits and other debt. As long as a bank is perceived either to be intrinsically solvent or to be supported at least implicitly by credible government guarantees, its managers can manage the stress by selling liquid assets and by borrowing funds from new depositors and from other institutions. However, when and as this perception fades, a bank is apt to experience silent and then open depositor runs.

A banking system experiences stress when many small banks or one or more of its largest banks fall into trouble at the same time. A systemic run occurs when large numbers of depositors try to redeem their deposits at many banks at the same time. In these circumstances, the supply of new deposits and private interbank loans tends to dry up and the central bank and government programs for guaranteeing bank liabilities come under manifest strain.

Caprio and Klingebiel (1999) describe a systemic run as a "borderline crisis" if some of the country's major banks suffer little erosion of their ownership capital. Episodes of systemic strain are designated as "systemic crises" if the systemic run reveals that most or all of the capital in the country's banking system is exhausted. Either type of crisis lasts until depositors' confidence in the convertibility of bank deposits can be restored.

This paper seeks to show that, during the last two decades, the banking systems of most African countries have been under more or less permanent stress and to explain why. Our explanation combines two factors: (1) depositors' vulnerability to loss: the persistent difficulties individual depositors encounter both in obtaining timely and reliable information on their bank's condition and in using such information to mitigate their exposure to loss; and (2) regulatory strategies that did not efficiently counteract these weaknesses because of the limited fiscal capacity and incentive conflicts under which regulatory policymakers operate.

Regulators' incentive structure implies that the probability that an African country will experience systemic distress increases not so much with the depth and breadth of 
individual banking insolvencies as with perceptions of fiscal weakness and corruptibility in its government. The weaker a government appears on these fiscal and ethical dimensions, the lower the level of depositor trust and the more easily banking distress can trigger an intervention-forcing customer run. Similarly, the fewer fiscal and ethical resources a government possesses, the more difficult it is for officials to negotiate a workable plan for setting a distressed banking system permanently back on its feet.

Section I pulls together empirical evidence on the character, depth, and duration of banking stress experienced in individual African countries during 1980-1999. Section II distinguishes six stages through which a banking crisis may proceed and hypothesizes that conflicts in policymaking incentives make institutions vulnerable and influence the sequence of stages that actually transpires in any particular crisis. Section III shows that this incentive-conflict hypothesis passes some crude regression tests. Section IV interprets the string of crises experienced in post-1980 Africa as "tuition": as transitory costs that the globalization of financial and regulatory markets made citizens in previously closed African banking systems pay to learn how conflicted the past performance of their bankers and regulators had been. The paper ends by listing three steps by which taxpayers and policymakers in Africa could reduce incentive conflict both in ordinary financial regulation and in disaster recovery. The better regulatory performance that better incentives would bring ought to dramatically improve the allocation of the Continent's economic resources.

\section{Data on African Banking Crises}

Table 1 documents and Figures 1A and 1B map the crises observed during 19801999 across the continent as a whole. Systemic crises were experienced in at least 50 of the continent's roughly 60 countries. Many of these crises proved long-lasting and 10 countries experienced additional rounds of banking weakness.

Statistical descriptions of when and why a bank fails focus on action-forcing events, such as unserviceable customer runs and proven violations of banking statutes. However, a bank seldom fails unless it first becomes deeply insolvent and insolvent banks often play fast and loose with their legal obligations. A bank is liquid as long as it can cover whatever obligations are currently falling due. Even banks that are mildly insolvent can usually raise liquid funds by selling off good assets or pledging them as 
collateral for loans.

The longer recapitalization is delayed, the deeper accumulated losses are apt to become. This is why crises inevitably lag the de facto impairment of bank loan portfolios. Crises do not emerge until efforts to circumvent the impairment of ownership capital break down. This breakdown alerts depositors that their wealth is seriously at risk. Resulting runs uncover the need to restructure local banking markets to effect the exit, outside takeover, or recapitalization of a multitude of damaged banks. In a crisis, taxpayers are asked to cover at least some of the costs of recapitalizing damaged banks and would have benefited from prompter regulatory discipline.

In contrast to the continent-wide view of crises taken in Table 1, Table 2 focuses more sharply on the experience of five selected sub-Saharan countries: Kenya, Nigeria, Uganda, Zambia, and Zimbabwe. The information this table summarizes comes from interviews with informed sources and data on major banking failures reported since 1995 on the Lexis-Nexis database. Panel B of this table supports the contention that individual bank failures tend to occur in waves. We maintain that failures are concentrated in time not so much because bad loans eat up the capital of individual banks at more or less the same instant. Rather, clustering occurs because the bureaucratic and personal interests of bank supervisors make them reluctant to force the recapitalization of important troubled banks until their ability to enhance the credit of insolvent banks comes under stress.

Figure 2 shows that the number of African countries encountering systemic distress trended upward until 1995 and is now receding slowly. We attribute both the surge and subsequent improvements to financial globalization. The surge came as opportunities increased for wealthy African depositors to book business on and off shore with foreign institutions. Improvements came from countries where domestic banks and regulators responded constructively to increased market discipline.

The frequency distribution plotted in Figure 3 indicates that the duration of banking distress in individual countries has often been protracted. Empirical tests in Section III employ the number of years each individual country spent in crisis as a proxy measure for the strength of the incentive conflict under which its regulatory officials operate. 
II. Bank Insolvencies, Banking Subsidies, and Silent Runs

1. Stability of a Financial System. "Stability" entails an ability to carry on in the face of disruptive changes in circumstances. To apply the word to financial systems, one must define what is supposed to be carried on and measure the effects of changing circumstances over an appropriate time frame. A country's financial system is stable as long as the array of banks and other financial institutions active in its markets provide credit and savings opportunities to its citizens in reasonable volume and on reasonable terms. This definition in no way excludes the possibility of dramatic changes over time in the identity of the individual firms that supply credit and savings products.

Financial instability occurs when the reliability of information about savings and investment opportunities deteriorates sharply enough to disrupt the flow of savings and investment. Ideally, regulatory strategies that focus on sustaining a given set of competitors over a succession of short periods may increase the system's long-run vulnerability to adverse informational and competitive shocks. Ideally, regulatory policies should aim at minimizing the costs society accrues over very long periods of time both from guarding against and from experiencing informational disruptions.

During the 1980s and 1990s, by the time an African bank became illiquid enough to force government intervention, its net worth was reduced almost entirely to taxpayer risk capital conveyed by explicit or implicit government guarantees. To prolong its existence after its ownership capital has departed, a bank has two instruments: accounting trickery and the black magic of backing up its deposits with the credit enhancements from its chartering government. Insolvent banks that enjoy such an unnatural prolongation of their existence may be likened to the soul-less creatures that horror movies call "zombies."

What makes zombie banks dangerous is their attraction to horrifically unfair and inefficient funding and lending strategies. These strategies damage a country's capital stock in two ways.

First, they support longshot --rather than prudently conservative-- patterns of real investment. To restore their firms' health, zombie managers need a number of quick and big wins. Prudent portfolio strategies cannot generate enough earnings to restore their depleted net worth quickly enough.

Second, a zombie's hurry to book numerous risky deals destroys the profit 
margins of healthy competitors. To improve its chances for resurrection, a zombie will pay unsustainably high interest rates for deposits and will accept unsustainably low contract interest rates on high-risk loans and investments. As Calypso singers tell us, zombies "don't give a damn; they done dead already." Moreover, as in a Ponzi scheme, accrued earnings can conceal economic losses. The high rates of contract interest that zombies can accrue on risky new loans sustain their accounting net worths at least until borrowers formally slide into arrears.

2. Politically Allocated Loans as a Source of Instability. The temptation for shortsighted politicians to use banking policies to serve redistributive tasks is particularly strong in polities that have only recently achieved independence. As a result, most African countries experience a zombified banking system at one time or another.

Redistributive policies make credit available to politically favored classes of borrowers at concessionary interest rates. To enlist the cooperation of banks, officials must subsidize banks along other dimensions: by fostering monopoly power and providing underpriced explicit or conjectural guarantees. Policies that support banks typically end up subsidizing bank risk-taking, so that the more credit, market, and operational risk a bank manages to take on, the greater its aggregate subsidy becomes.

Crises develop because taxpayers cannot effectively monitor and control the linked subsidies. In African countries, the contracting and reporting framework under which regulatory officials work does not make them directly accountable for measuring and controlling the size of either subsidy. For example, Table 3 shows that only a fifth of the governments experiencing crisis in Table 1 have provided reliable information on the ex post costs of crisis resolution. The median reported cost lies between 6 percent and 10 percent of GDP. Resolution costs are probably understated in this sample and taxpayer costs are almost certainly higher in nonreporting venues.

The opportunity costs taxpayers face in government credit-allocation schemes are hidden by historical-cost accounting methods that assign par values to loans that carry below-market interest rates. In principle, every time a bank books a politically preferred loan at face value, it conceals an opportunity loss. The loss comes from the gap that exists between the loan's expected rate of return and the yield needed to compensate the bank fully for the default risk it entails.

To an economist, a bad loan or investment is one whose fair market value lies 
below the value at which it is booked. The greater the difference between a loan's market value and book value, the worse the loan is. The more such loans are made and the larger the interest gap they carry, the more a bank's accounting net worth overstates the economic value of ownership claims to the bank's future earnings.

In contrast, the historical-cost criteria used in financial accounting treat every loan as a good loan until it falls sufficiently into arrears. At that point, slow loans are reclassified as "nonperforming loans" (NPL). Unless delays in loan service reach the NPL threshold, interest income is accrued as scheduled even if the bank has not received the payments due. Even when a loan is classified as NPL, its book value is seldom marked to market. However, unpaid accruals are reversed and subsequent payments are posted only as received. The desire to avoid reversing accruals makes zombie banks eager to use new loans or interest reserves to keep loan service current.

In Table 1, the level of NPLs at African banks is put forward as a measure of the depth of individual crises. Figure 4 clarifies how unreliable country-level NPL data must be by underscoring the gaps in yearend NPL information that is available on the FitchIBCA database for forty Kenyan banks in 1995, 1996, and 1997. On average, less than half of the banks reported NPLs in any year and only seven banks reported NPLs in all three years. Even worse, sources we interviewed maintained that, even at banks that supplied NPL data to FitchIBCA, the true value of NPL was often a large multiple of the reported figure.

3. Early Stages of Financial Crisis. Troubled banks have an incentive to report good news promptly and to suppress bad news as long as possible. Because opportunity losses are not recognized promptly in bank accounting statements, the net worth positions of troubled banks is routinely overstated. This overstatement makes a hash of alleged capital "requirements." Treating accounting capital as economic capital is a subtle form of capital forbearance by regulators. In the short run, the forbearance is hidden by uninformative valuation principles. Although cosmetic accounting cannot mislead sophisticated depositors, informed customers do not discipline zombie banks until they lose confidence that the costs of covering government guarantees can be truly and firmly shifted to taxpayers.

As Table 4 indicates, Kane (1999a) partitions financial crises into six stages. The first three stages are governed mainly by incentive distortion in the private economy, 
while the last three are propelled by incentive distortion in government.

In the first stage, government-influenced lending turns banks into institutional zombies. In the second stage, silent runs occur as doubts surface about the government's ability to support its two-part subsidy scheme.

These doubts limit new fundraising by zombie banks, making it hard to sustain their positive net worth by Ponzi accounting. In the second stage, each zombie's savviest depositors insist either on being offered good collateral or on receiving a discriminatorily higher interest rate than the bank quotes to less-informed customers.

In a developing country, silent runs by wary accountholders are often initially financed by an infusion of collateralized foreign-bank debt. As foreign banks' position expands, acceptable collateral becomes harder and harder to come by. At this juncture, foreign banks simultaneously curtail the flow of funds to zombie banks and begin to speculate against the exchange rate. With access to credit blocked and with foreign banks speculating against the exchange rate, zombie banks and their government may be forced to take desperate steps.

Unless the system's economic insolvencies are promptly resolved, a second-stage silent run threatens to turn into a third-stage open run and bureaucratic breakdown. The substitute funding comes from increasingly informed creditors on progressively more onerous terms. Paying these tougher terms squeezes bank profit margins and helps to generate poor accounting performance. This transmits adverse information about the banks to the less-informed customers and feeds rumors of systemic insolvency. As these rumors reach the ears of less-sophisticated domestic depositors, the run accelerates and challenges more and more severely the credibility of the government's guarantee arrangements.

4. Role of Vulnerability-Generating Policy Strategies. Until the 1980s, the prototypical African economy was tightly controlled. Its financial sector was concentrated and highly bank-dependent, with little effective competition for loans or deposits. Financial institutions were often state-owned. These banks were inefficient, overstaffed, and loans were not made by value-maximizing principles. Even where banks were privately owned, management and internal controls were weak. Artificial barriers to foreign-bank entry were enforced. Households tended to rely on currency to make transactions. Fiscal and monetary policies were loose. Inflation was high and exchange rates tended to be 
overvalued. Financial crises were frequent and long-lasting.

This policy strategy is vulnerable to technologically driven competition from foreign banks and their regulators. This vulnerability is intensified in countries where government credit-allocation schemes and risk-bearing subsidies impose adverse longrun effects on the banking system. Microeconomically, banks benefit in the short run from receiving a net subsidies, but the unfavorable long-run effect of the scheme is to undermine the economic value of bank capital.

Banking policies that tolerate undercapitalized institutions distort bank lending and borrower investment incentives toward imprudently high-risk alternatives (Ncube and Senbet, 1995; Lindgren, Garcia, and Saal, 1996). Banks are tempted to respond to subsidies to risk-taking by booking as much of the subsidized risks as they can. Because the resulting risk exposures are left underdiversified, the probability of incurring losses large enough to wipe out the bank's net worth is high. Informed bank stockholders tolerate such potentially ruinous gambles because of the subsidies they generate. ${ }^{1}$

Table 5 outlines how policy-generated vulnerability turns into financial crisis. The conflict between the helpful short-run and damaging long-run effects may be understood as a disequilibrating collision of an Hegelian thesis with its antithesis. Over a succession of short periods, these opposing forces evoke a series of adjustments in regulatory strategy (new Hegelian syntheses). However, in the absence of a severe crisis, it is difficult for short-horizoned political leaders to frame a synthesis that is entirely free of long-run contradiction.

Simultaneously supporting and damaging the banking system induces a harmful dialectic in macroeconomic policy. In this dialectic, bank insolvencies and creditallocation policies generate implicit debt that undermines the sustainability of government guarantees, while politically determined patterns of investment destroy wealth and reduce export capacity. As impaired loans loom larger and larger on bank balance sheets, the unbooked losses they generate erode the comfort creditors can take from accounting net worth. By increasing the effective leverage of the banking system, programmed-loan expansion shifts risk toward bank creditors. As the allocation program expands, banks become less able to compensate or protect their creditors adequately and

\footnotetext{
${ }^{1}$ If they wish, stockholders may even neutralize the risk to their personal net worth by arbitraging some of their risk exposure in foreign markets.
} 
their survival depends increasingly on prospects for government assistance.

Especially in countries where explicit deposit insurance does not exist, it is hard to make authorities accountable for the ways they manage the conflict between government lending priorities and the fiscal drain caused by supporting insolvent banks. It is even harder when the zombie banks are state-owned. Although the accounts of stateowned banks are kept formally separate from those of the government, depositors expect taxpayers to back up virtually without limit whatever obligations the bank assumes.

Zombie banks can only survive as long as creditors may rationally assume that the government's capacity to obtain future tax revenue can simultaneously cover both the targeted exchange rate and the taxpayer bailout that the banking system's insolvency demands. To express the banking-policy switchpoint algebraically, we let the shortfall between the opportunity-cost value of banking-system assets and the nominal value of system liabilities define a maximal potential bank bailout $\left(\mathrm{B}_{\mathrm{G}}\right)$. We write the value of the future tax revenues that the government may realistically be expected to devote to bailing out banks as $\mathrm{T}_{\mathrm{G}}$. As growth in $\mathrm{B}_{\mathrm{G}}$ approaches and then outstrips $\mathrm{T}_{\mathrm{G}}$, it lessens authorities' ability to support the exchange rate and it rewards savvy domestic depositors who can: reassess bank accounting reports, participate in a silent run, and speculate against the exchange rate.

In the macroeconomy, short-run surges in employment and national income are generated by the incremental investment spending the credit-allocation program supports. However, each dollar perceived to be committed to bailing out insolvent banks corresponds to a debt-financed expenditure of taxpayer funds. Hence, as in Krugman's (1979) first-generation model of currency crisis, the policy's unfavorable long-run effects come from the impact in foreign-exchange markets of the fiscal weakness that the continual buildup of taxpayer risk capital entails. To induce destabilizing speculation, the government's exchange-rate target need not be absolutely fixed. Where policymakers seek to hold fluctuations in currency value within a narrow band, the unbooked increase in debt will eventually push the currency's price to the bottom of the band.

In a pure currency crisis, market testing takes the form of a bear raid. In successful raids, the bears eat up the government's foreign-exchange reserves.

In a pure banking crisis, the test is a silent run. A government that shores up its guarantee system can adjust its banking policies to stop or reverse a silent run before it 
erupts into open crisis. However, in dealing with an emerging banking crisis, most governments look initially to increase the liquidity of their banking systems while cleaning up just enough of the banking system's accrued losses to restore the credibility of future bailouts. A lasting policy synthesis seldom occurs until the cumulative social cost of fighting bear raids and open runs forces authorities to confront the need to improve incentives in the banking system.

5. Role of IMF Lending in Crisis Prolongation. In the face or regulatory incentive conflict, large amounts of external aid may merely push a country's fundamental policy crisis underground. In any case, IMF lending tends to diminish the market discipline regulators feel in the face of crisis (Bird, Hussain, and Joyce, 2000; Calomiris, 1998). The loans increase the credibility of the recipient government's promises to protect bank depositors, which makes it feasible for these governments to gamble anew that the zombies can lend their way out of their insolvency. Crisis discipline is minimized when policymakers restore their credibility by drawing on external aid that is not itself markettested (e.g., via collateralized loans from the IMF or structural adjustment credits from World Bank). IMF conditionality seldom exerts strong pressure either to resolve insolvencies or to commit explicit funds to strengthening the guarantees. When a country's crisis management only partially resolves systemic insolvency, a deeper round of bear raids and silent runs is likely to ensue later.

IMF lending inevitably demands changes in a country's macro policy mix, but typically the changes specified stabilize the recipient country's exchange rate at the expense of the population's previously expected improvements in their standard of living. The reduced standard of living further increases the risk of subsequent bank insolvency by reducing the ability of the average borrower to service its debts and by threatening popular discontent. If discontent turns to unrest, the threat of coups, riots, and civil war introduces further complications.

6. Globalization as an Accelerant of Crisis. In effect, systemic crises are a form of market discipline. "Discipline" is punishment inflicted as correction or training in hopes of producing improved behavior. In competitive markets, customers and competitors punish banks for pricing or servicing customer demands inefficiently and for taking imprudent risks with depositor funds.

Economic globalization disciplines historically separated regional and national 
markets by incorporating them into a broader price-making environment. This occurs because technological and organizational change destroys distance-related, culturallybased, and regulatory barriers to cross-national competition.

The intensity of global pressure grows over time with advances in information and contracting technology. Pressure also increases with the size of the gap which exists between the efficiency and fairness of the host-country regulatory scheme and the schemes under which the foreign-bank entrants operate. Reduced profit margins and increased cyclical stress destroy the ability of inefficient domestic banks to credibly project future profits. This throws the sustainability of implicit government support for insolvent zombie institutions into increasing doubt and this doubt triggers silent runs.

In developing countries, technological change that speeds the globalization of domestic capital markets challenges regulators both economically and politically. Economically, the challenge is twofold: using foreign markets to lessen the exposure to financial shocks inherent in an individual country's concentration of real capital in a few, economically vulnerable industries (Levine, 1997; Rodrik, 1998) and recognizing how loopholes and outside regulatory arrangements limit the regulatory strategies a local regulator can enforce. Politically, the required sequence of market-structure adjustments is painful to contemplate. The challenge is to persuade well-connected institutions that have traditionally dominated these countries' financial markets to abandon protected and subsidized ways of doing business.

Most developed countries have allowed their domestic banks to book a wider range of risks in foreign subsidiaries than they would tolerate in home-country offices. Politicians understand that relationships with internationally active customers are geographically footloose and they don't expect to be held accountable for overseas banking losses in domestic political arenas. This has encouraged banks in developed countries such as Japan and the U.S. to "overlend" in foreign markets. In turn, hostcountry authorities have been persuaded --by technological change and well-placed side payments-- to relax longstanding barriers to the entry of foreign financial firms. The more corruptible a country's government, the easier it is apt to be for foreign banks to negotiate limited entry privileges.

Officials in a host government can smooth the internal politics of limited entry by emphasizing the basic fairness of allowing a foreign bank to follow its longstanding 
home-country customers into a venue in which the bank's customers are helping the host government to expand domestic income and employment. From a small foothold, a clever foreign bank can gradually expand its range of business. This gradual expansion in product offerings puts downward pressure on the interest-rate spreads that host-country banks can earn (Claessens, Demirgüç-Kunt, and Huizenga, 1997). This pressure is felt most keenly when cyclical weakness in domestic loan repayments aggravates macroeconomic stresses on a zombified system of host-country banks. It is in these circumstances that host-country banks can most rapidly lose domestic market share.

In markets for regulatory services, officials who do not respond to outside regulatory competition suffer reductions in their client base and budgetary resources. This is because globalization makes it easier for worried depositors to place their wealth under the shelter of foreign guarantees. As $\mathrm{B}_{\mathrm{G}}$ rises, so do depositor worries about the government's ability to fulfill its promises to support the exchange rate and to support banking insolvencies. As $\mathrm{B}_{\mathrm{G}}$ approaches its maximum sustainable level $\mathrm{T}_{\mathrm{G}}$, offshore suppliers of higher-quality regulatory and guarantee services exert increasing market discipline.

For any host country, the initial entry of outside banks entails capital inflows. However, in the long run, when host-country banks are insolvent, the presence of foreign institutions facilitates depositor runs, so that dramatically larger capital outflows are apt to follow. Such outflows can be halted temporarily by capital controls. However, until the breakdown of the host-country support system is repaired, inventive contracting technologies will progressively undermine the effectiveness of capital controls. As a consequence, lobbying pressure will develop in the business community to legitimate offshore borrowing and to reverse the outflow of host-country wealth. This will eventually encourage domestic authorities to adopt regulatory schemes that curtail subsidies to insolvent banks.

After one or more incomplete recapitalizations have failed, the political difficulty of fully recapitalizing zombie institutions with explicit taxes may tempt authorities to open their markets to foreign rescuers. Presuming that they can cut a good deal, foreign banks would be eager to help a beleaguered host government to reduce the costs of recapitalizing the system by taking insolvent banking franchises off the government's hands. 
III. Regression Tests of the Incentive-Conflict Hypothesis

A banking crisis is at heart a dispute about how to distribute across society the opportunity losses that zombie banks have amassed. When a bank faces palpable distress, its managers quickly formulate a plan for turning their bank around and lobby authorities to give them time for the plan to take effect. Many turnaround plans amount to a positively skewed, negative-present-value "gamble for resurrection." Such gambles damage taxpayers by shifting downside risk onto the government and damage healthy banks by forcing them to offer unsustainably high deposit rates and to accept unsustainably low interest rates on new loans. The long-run efficiency of a country's program for restructuring distressed banks turns on its government's willingness and ability to arrest resurrection gambling by cleaning up loan losses and forcing the recapitalization, merger or liquidation of all zombie banks. Transferring nonperforming loans to underfunded banking entities (as in Mexico in 1994) represses rather than treats the symptoms of crisis. It trades temporary relief for a probable recurrence of stronger crisis pressures down the line.

Around the world, in crises whose costs have been publicly reported, taxpayer losses range principally between 1 and 10 percent of GDP (Caprio and Klingebiel, 1996a and 1999). Section II asserts that the level of unbooked losses that depositors will allow a nation's banks to accumulate is restrained both by the reliability of the nation's information environment and by the credibility of government efforts to supervise and guarantee the faithful performance of bank contracts. Such reliability and credibility rises with the extent to which regulators' incentive conflict is mitigated by cultural restraints and reporting provisions that make them accountable for taxpayer losses.

We propose to proxy cross-country differences in accountability and cultural restraints by indexes of government corruptibility (C) and press restraint (PR). Table 6 lists the value of two such indexes for a few benchmark countries and every African nation for which these data exist. The table also reports the real per capita value of gross domestic product (GDP).

Corruption is measured by Transparency International's Corruption Perception Index (TICPI). The TICPI derives from a series of independent surveys of business executives. The surveys ask sample respondents to estimate on an inverse 10-point scale 
the level of corruption in countries with which they have firsthand experience. A score of 10 would represent a "perfectly clean" country. A score of zero would signal the maximum imaginable incidence of kickbacks, bribery, extortion, and fraud in business and government transactions. To reverse the sense of the index, in our regression experiments we measure corruption (C) as TICPI divided by 10.

Press restraint (PR) is represented by the index compiled by Freedom House staff in the 1999 edition of their annual Press Freedom Survey. This index measures the extent to which repressive actions, laws, regulations, controls, and political pressures influence media content. We adjust their scale to run from zero to 10 , with lower scores indicating greater freedom.

Because skeptical depositors cannot easily verify the reliability of bank accounting data, it is rational for depositors to monitor and react to news concerning the character and reputation of bankers and bank supervisors. The weaker the ethical and legal restraints that condition a country's business environment, the more depositors and taxpayers have to fear from corrupt, incompetent, or opportunistic bankers and government officials. Similarly, the less press freedom a country has the more difficult it is to hold officials accountable for their actions. We hypothesize that the persistence of unresolved loan losses in a country's banking system is directly related to PR and C. The more the press is restricted and the greater the perception of corruptibility in government procedures for enforcing the honorable performance of business contracts, the more exposed depositors should feel to losses from corrupt or imprudent lending.

Other things equal, the higher are PR and $\mathrm{C}$, the more quickly and energetically depositors should respond to rumors of bank weakness. This leads to the testable hypothesis that, across countries, the recurrence of crises in depositor confidence and the average length of time spent locked in unresolved distress would vary directly with proxies for these variables.

Taxpayers' interest in mitigating their exposure to loss should intensify the negative correlation between the frequency of crises and regulator accountability. Worldwide, the importance of accountability is supported by the empirical findings of Demirgüç-Kunt and Detragiache (1997). Differences in the relative frequency of banking crises between countries that rank in the top and bottom tiers of the full 99-country TICPI rankings uphold this idea as well. Countries in Africa, Latin America, and Eastern 
Europe -where systemic crises have been commonplace-- dominate the lower three quarters of the country rankings. Finally, in Africa, the more frequent recurrence of banking problems in low-TICPI countries than in high-TICPI nations further supports both the accountability and vulnerability-mitigation hypotheses.

Table 7 investigates the correlation between crisis persistence and government corruption. The regression experiments include all African countries for which we found reliable data on the included variables. Each experiment makes the number of years that a country spent in crisis between 1980 and 1999 the endogenous variable, Y. On the grounds that corruption and governmental nontransparency undermine the credibility of officials' efforts to negotiate and enforce agreements to allocate the accumulated opportunity losses in zombie banks across society, the following hypothesis is tested: Either singly or in combination, corruption (C) and restrictions on press content (PR) delay the resolution of insolvent banks. We include real per capita GDP as a potential control variable, on the grounds that the resources authorities need to promptly resolve a crisis increase with a country's level of development.

Although PR and GDP each receive the predicted coefficient signs, their coefficients are never significant, either by themselves or in combination with one or both of the other regressors. On the other hand, the influence of $\mathrm{C}$ is significant at 5 percent, and its significance weakens only slightly when either of the other variables is included as a control. Although the sample is small and our regression models are ad hoc, the result gains credence both from the commonsense strength of the prior and from the statistical power that is sacrificed in treating differences in corruption as if they were constant across countries over time.

\section{Rendering African Regulators More Accountable}

Inevitably, supervisory standards and incentives are country-specific and politically compromised. African taxpayers and depositors would be better able to protect themselves if banks and their regulators adopted information systems that made bank capital and risk exposure more transparent to outside parties. Taxpayers would be helped further if regulatory response schemes were designed to reinforce rather than neutralize market discipline.

In dealing with troubled institutions, officials are often sorely tempted to promote 
their bureaucratic and career interests. The best way to recycle bad loans is to insist that stockholders or taxpayers recapitalize explicitly the banks that own these loans. It is poor policy to leave bad loans on the books of zombie institutions at inflated values and to try to fool the public into thinking that this strategy poses a fair gamble for taxpayers. African countries experienced so many banking crises in 1980-1999 because incentive conflict shortened decisionmaking horizons so that myopic policymaking offered officials better reputational and career payoffs than optimal policies would.

The frequency, duration, and geographic extent of banking crises demonstrate that numerous African banks found it reasonable to book potentially ruinous risks. Authorities deserve blame for actively encouraging loss-causing patterns of credit allocation and for compounding the damage by not resolving individual-bank insolvencies until their situations had deteriorated disastrously.

In Africa, supervisory empowerments and social controls on the job performance of regulators responsible for protecting the safety and soundness of financial institutions are inadequate. Poor information flows and incentive conflict in policymaking expose African bank depositors to risks that leave their country alternating between states of repressed and open crisis and perennially misallocating domestic savings.

Panic models of crisis developed by Minsky (1977) and Kindleberger (1978) imply that in a crisis the best regulators can do is to look for ways to moderate exogenously determined and irrational swings in mob psychology. In our model, swings in consumer confidence are predominantly functions of economic news. Incentive conflict in regulation enlarges the extent of overvaluation in boomtimes and contributes to the suddenness of corrective downward swings in asset valuation. Confidence declines suddenly when blockages in the flow of bad news break down. Depositor runs develop as rational responses to a deterioration in public information about banks.

Suppressing adverse information during economic booms allows asset prices to rise too high, while the abrupt surfacing of hidden information leads to a sharp downward revaluation of perceived bank net worth. The root both of asset-price bubbles and of their abrupt bursting is the interaction of a popular appetite for comforting delusions with a self-interested, cooperative effort by banks and regulators to conceal adverse information from depositors and taxpayers.

In our model, bogus accounting is an artifact of incentive-conflicted regulation. 
Our model's policy remedy is to reduce blockages in the flow of adverse information about banks and regulatory performance.

Making regulators more accountable begins with imposing and enforcing adequate disclosure protocols on banks. The first step is to collect data from individual institutions about the value of their capital and the extent of their vulnerability to particular risks. Ideally, regulators should check the information they collect by means of credit-scoring technology. To do this, each bank should be made to disclose and document carefully the methods it uses to measure and price its credit exposures. To calibrate the exposure of individual institutions to other kinds of loss, data collected ought to allow a detailed evaluation of the effectiveness of the bank's diversification and hedging programs. All information an institution reports should be routinely verified by periodic audits and on-site examinations. To insulate these tasks from changes in government, it might be advisable to write into a country's constitution a requirement that regulators periodically measure the value of each institution's capital on an opportunitycost basis and weigh this against a market-based estimate of the net exposure to loss the bank's risky positions require this capital to cover.

The second step is to combine bank-level information into an index of the robustness of a country's financial system as a whole. As a minimum, regulators should seek to combine data on individual-bank credit-risk exposures, risk-control programs, and leverage into an explicit estimate of the aggregate credit risk that each bank shifts implicitly onto the government's safety net. To control risk shifting, regulators must police the social cost of individual-bank credit exposures carefully and be empowered to force each bank to eliminate or pay for undue risk. One way to determine the appropriate level of risk allowances that apply on any assessment date, would be for authorities to explicitly hedge the taxpayer's estimated exposure to loss in offshore derivatives or insurance markets.

However, to incorporate individual-bank assessments into a measure of their country's system of institutions, regulators must first estimate how much correlation exists in the net risk exposures of different institutions. This correlation is apt to be high in countries whose foreign-exchange rate is highly volatile or whose economic activity is concentrated in a few industries. The more returns are correlated across banks, the more likely it is that individual institutions will fall into trouble at the same time. 
The third step is to assure that the system can efficiently absorb a disastrous event. This requires building an administrative capacity to quickly and cheaply restore aggregate savings and borrowing opportunities in the face of a catastrophic macroeconomic or industry shock. Addressing this issue entails recognizing authorities' inability to prevent the occasional occurrence of calamitous events and setting up and publicizing a contingent plan for handling financial disaster. Just as governments around the world dealt in 1999 with the threats to their computer systems raised by Y2K, creating a disaster-recovery plan means assembling and regularly rehearsing teams of appropriately skilled experts. To minimize the time spent in financial crisis, the experts assembled must be able to make a quick and dirty evaluation of the depth of every troubled institution's potential insolvency. These evaluations would serve two purposes: to direct central-bank financial assistance toward solvent institutions and to promptly allocate losses accrued in institutions that are demonstrably insolvent across individual stakeholders in accordance with pre-existing contractual rights and obligations.

The goal is to enable and to incent African authorities to take prompt, costminimizing action both to forestall emergencies and to resolve them when they occur. Economic theory suggests that the likelihood of achieving this result depends crucially on the existence of information flows that can make regulators' accountable to taxpayers for losses properly attributable to bad planning and execution. 


\section{REFERENCES}

Bird, Graham, Mumtaz Hussain, and Joseph Joyce, 2000. "Many Happy Returns?

Recidivism and the IMF," Wellesley College Working Paper \#2000-04 (March).

Calomiris, Charles, 1998. "Blueprints for a New Global Architecture," New York:

Columbia University (Sept. 23).

Caprio, Gerard, and Daniela Klingebiel, 1996a. "Bank Insolvency: Bad Luck, Bad

Policy, or Bad Banking?,” Annual Conference on Development Economics, Washington: The World Bank, pp. 79-104.

, 1999. "Episodes of Systemic and Borderline Financial Crises," Washington: The World Bank (October).

Claessens, Stijn, Aslı Demirguç-Kunt, and Harry Huizenga, 1997. "How Does Foreign Entry Affect the Domestic Banking Market?,” Washington: The World Bank Development Group (unpublished).

Demirgü५-Kunt, Aslt, and Enrica Detragiache, 1997. “The Determinants of Banking Crises: Evidence from Developed and Developing Countries," World Bank and International Monetary Fund, Washington, D.C.

Deschamps, Jean-Jacques, and James Bonnardeaux, 1997. "Bank Restructuring in SubSaharan Africa: Lessons from Selected Case Studies,” World Bank Working Paper, Private Sector Finance, Africa Region (May).

International Monetary Fund, 2000. "International Financial Statistics," Washington: IMF (April).

Jbili, Abdelali, Klaus Enders, and Volker Treichel, 1997. "Financial Sector Reform in Algeria, Morocco, and Tunisia: A Preliminary Assessment," International Monetary Fund Working Paper (July).

Kane, Edward J., 1999a. "Capital Movements, Banking Insolvency, and Silent Runs in the Asian Financial Crisis," Pacific Basin Finance Journal 8(May), pp. 153-175. , 1999b. "How Offshore Financial Competition Disciplines Exit Resistance by Incentive-Conflicted Bank Regulators," Journal of Financial Services Research 16(September/December), pp. 265-291.

Kindleberger, Charles P., 1978. Manias, Panics and Crashes: A History of Financial Crises, New York: Basic Books, Inc. 
Krugman, Paul, 1979. “A Model of Balance-of-Payments Crises,” Journal of Money, Credit, and Banking (August), pp. 311-325.

Levine, Ross, 1997. "Financial Development and Economic Growth: Views and Agenda," Journal of Economic Literature, 35(June), pp. 688-726.

Lewis, Peter, 1995. "Banking Privatization in Nigeria: Background, Context and Prospects," draft.

Lindgren, Carl-Johan, Gillian Garcia, and Matthew I. Saal, 1996. Bank Soundness and Macroeconomic Policy, Washington: The International Monetary Fund.

Minsky, Hyman, 1977. "A Theory of System Fragility," in Edward Altman and Arnold Sametz (ed.), Financial Crises: Institutions and Markets in a Fragile Financial Environment, New York: Wiley-Interscience.

Ncube, Mthuli, and Lemma W. Senbet, 1995. "Perspectives on Financial Regulation and Liberalization in Africa under Incentive Problems and Asymmetric Information," Journal of African Economies, Vol. 6, No. 1, (AERC Supplement), pp. 29-88.

Rodrik, Dani, 1998. "Trade Policy and Economic Performance in Sub-Saharan Africa," National Bureau of Economic Research Working Paper No. 6562 (May). 


\section{TABLE 1}

\section{EPISODES OF MAJOR BANKING INSOLVENCIES IN AFRICAN COUNTRIES, 1980-1999}

\begin{tabular}{|c|c|c|}
\hline $\begin{array}{l}\text { Country and } \\
\text { Dates }\end{array}$ & Scope of Crisis & Depth of Crisis \\
\hline $\begin{array}{l}\text { Algeria } \\
1990-1992\end{array}$ & Systemic & $\begin{array}{l}\text { Banking system non-performing loan ratio (NPLs) reached } 50 \\
\text { percent. }\end{array}$ \\
\hline \multicolumn{3}{|r|}{ ( } \\
\hline $1991-?$ & Borderline & Two state-owned commercial banks experienced solvency problems. \\
\hline \multicolumn{3}{|l|}{ Benin } \\
\hline $1988-1990$ & Systemic & $\begin{array}{l}\text { All three commercial banks collapsed; } 80 \text { percent of banks' loan } \\
\text { portfolio was non-performing }\end{array}$ \\
\hline \multicolumn{3}{|l|}{ Botswana } \\
\hline 1994-1995 & Borderline & $\begin{array}{l}\text { One problem bank was merged in 1994, a small bank was liquidated } \\
\text { in 1995, and the state-owned National Development Bank was } \\
\text { recapitalized. }\end{array}$ \\
\hline \multicolumn{3}{|l|}{ Burkina Faso } \\
\hline 1988-1994 & Systemic & Banking system NPLs estimated at 34 percent. \\
\hline \multicolumn{3}{|l|}{ Burundi } \\
\hline 1994-? & Systemic & $\begin{array}{l}\text { Banking system NPLs estimated at } 25 \text { percent in 1995; one bank was } \\
\text { liquidated. }\end{array}$ \\
\hline \multicolumn{3}{|l|}{ Cameroon } \\
\hline $1987-1993$ & Systemic & $\begin{array}{l}\text { In 1989, banking sector NPLs reached } 60-70 \text { percent. Five } \\
\text { commercial banks were closed, three banks were restructured. }\end{array}$ \\
\hline $1995-1998$ & Systemic & $\begin{array}{l}\text { At end1996, NPLs accounted at } 30 \text { percent. Three banks were } \\
\text { restructured and two were closed. }\end{array}$ \\
\hline \multicolumn{3}{|l|}{ Cape Verde } \\
\hline 1993-? & Systemic & At end1995, commercial banks' NPLs amounted to 30 percent. \\
\hline \multicolumn{3}{|l|}{ Central African } \\
\hline 1976-1992 & Systemic & Four banks were liquidated. \\
\hline 1995-1999 & Systemic & $\begin{array}{l}\text { The two largest banks, accounting for } 90 \text { percent of total assets, were } \\
\text { restructured. Banking sector NPLs amounted to } 40 \text { percent. }\end{array}$ \\
\hline \multicolumn{3}{|l|}{ Chad } \\
\hline $1979-1983$ & Systemic & $\begin{array}{l}\text { Seventy-five percent of loans to the private sector were } \\
\text { nonperforming; } 2 \text { state-owned banks were liquidated and } 2 \text { other } \\
\text { state-owned banks were privatized. }\end{array}$ \\
\hline $1980 \mathrm{~s}$ & Systemic & \\
\hline 1992 & Systemic & Private sector NPLs amounted to 35 percent. \\
\hline
\end{tabular}




\begin{tabular}{|c|c|c|}
\hline $\begin{array}{l}\text { Country and } \\
\text { Dates }\end{array}$ & Scope of Crisis & Depth of Crisis \\
\hline \multicolumn{3}{|l|}{$\begin{array}{l}\text { Congo } \\
\text { (Brazzaville) }\end{array}$} \\
\hline 1992-? & Systemic & $\begin{array}{l}\text { Two large banks placed in liquidation. The remaining three banks are } \\
\text { insolvent. Situation aggravated by civil war. }\end{array}$ \\
\hline \multirow{2}{*}{\multicolumn{3}{|c|}{$\begin{array}{l}\text { Congo, Democratic } \\
\text { Republic of } \\
\text { (former Zaire) }\end{array}$}} \\
\hline & & \\
\hline $1980 \mathrm{~s}$ & Systemic & \\
\hline 1991-1992 & Systemic & $\begin{array}{l}\text { Four state-owned banks insolvent; a fifth bank was recapitalized with } \\
\text { private participation. }\end{array}$ \\
\hline 1994-? & Systemic & $\begin{array}{l}\text { NPLs to the private sector reached } 75 \text { percent; two state-owned banks } \\
\text { liquidated and two other state-owned banks privatized. In 1997, } 12 \\
\text { banks in serious difficulty. }\end{array}$ \\
\hline \multicolumn{3}{|l|}{ Côte d'Ivoire } \\
\hline 1988-1991 & Systemic & $\begin{array}{l}\text { Four large banks affected, which held } 90 \text { percent of banking system } \\
\text { loans; three definitely and one perhaps insolvent. Six government } \\
\text { banks were closed. }\end{array}$ \\
\hline \multicolumn{3}{|r|}{ ( } \\
\hline $1991-1993$ & Systemic & $\begin{array}{l}\text { Two of six commercial banks ceased operations in } 1991 \text { and 1992; } \\
\text { other banks experienced difficulties. }\end{array}$ \\
\hline \multicolumn{3}{|l|}{ Egypt } \\
\hline $1991-1995$ & Borderline & Four large Public Sector banks were recapitalized. \\
\hline \multicolumn{3}{|c|}{ Equatorial Guinea } \\
\hline 1983-1985 & Systemic & Two of the country's largest banks were liquidated. \\
\hline \multicolumn{3}{|l|}{ Eritrea } \\
\hline 1993- & Systemic & Most of the banking system insolvent. \\
\hline \multicolumn{3}{|l|}{ Ethiopia } \\
\hline 1994-1995 & Borderline & $\begin{array}{l}\text { A government-owned bank was restructured, and its non-performing } \\
\text { loans were taken over by the Government. }\end{array}$ \\
\hline \multicolumn{3}{|l|}{ Gabon } \\
\hline 1995-? & Borderline & One bank was temporarily closed in 1995. \\
\hline \multicolumn{3}{|l|}{ Gambia } \\
\hline 1985-1992 & Borderline & In 1992, a government bank was restructured and privatized. \\
\hline \multicolumn{3}{|l|}{ Ghana } \\
\hline 1982-1989 & Systemic & Seven of 11 audited banks insolvent; rural banking sector affected. \\
\hline 1997-? & Borderline & $\begin{array}{l}\text { NPLs increased sharply during } 1997 \text { from } 15.5 \text { percent of loans } \\
\text { outstanding to } 26.5 \text { percent. Two state-owned commercial banks in } \\
\text { bad shape, with } 33.9 \text { percent market share. Three banks insolvent, } \\
\text { with } 3.6 \text { percent of market. }\end{array}$ \\
\hline
\end{tabular}




\begin{tabular}{|c|c|c|}
\hline $\begin{array}{l}\text { Country and } \\
\text { Dates }\end{array}$ & Scope of Crisis & Depth of Crisis \\
\hline \multicolumn{3}{|l|}{ Guinea } \\
\hline 1985 & Systemic & Six banks with 99 percent of industry deposits deemed insolvent. \\
\hline 1993-1994 & Systemic & $\begin{array}{l}\text { Two insolvent banks had } 22.5 \text { percent of financial system assets; one } \\
\text { other bank in serious financial difficulties; these three banks } \\
\text { accounted for } 45 \text { percent of the market. }\end{array}$ \\
\hline \multicolumn{3}{|l|}{ Guinea-Bissau } \\
\hline $1995-?$ & Systemic & At end1995, NPLs were 45 percent of total loans. \\
\hline \multicolumn{3}{|l|}{ Kenya } \\
\hline $1985-1989$ & Systemic & $\begin{array}{l}\text { Four banks and } 24 \text { nonbank financial institutions with } 15 \text { percent of } \\
\text { system liabilities faced liquidity and solvency problems. }\end{array}$ \\
\hline 1992-1995 & Systemic & $\begin{array}{l}\text { Banks holding more than } 30 \text { percent of industry assets had solvency } \\
\text { problems. }\end{array}$ \\
\hline 1996-? & Borderline & $\begin{array}{l}\text { At end of 1996, NPLs reached } 18.6 \text { percent of total banking system } \\
\text { loans. }\end{array}$ \\
\hline \multicolumn{3}{|r|}{ ( } \\
\hline $1988-?$ & Borderline & $\begin{array}{l}\text { Of four commercial banks, one small bank had a large portfolio of } \\
\text { non-performing loans. }\end{array}$ \\
\hline \multicolumn{3}{|r|}{ 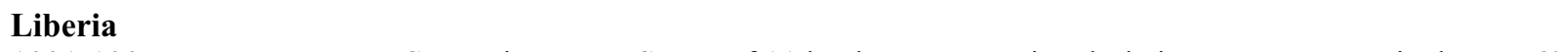 } \\
\hline 1991-1995 & Systemic & $\begin{array}{l}\text { Seven of } 11 \text { banks not operational; their assets were equivalent to } 60 \\
\text { percent of industry assets at mid-1995. }\end{array}$ \\
\hline \multicolumn{3}{|l|}{ Madagascar } \\
\hline 1988 & Systemic & 25 percent of banking sector loans deemed irrecoverable. \\
\hline \multicolumn{3}{|l|}{ Mali } \\
\hline 1987-1989 & Systemic & NPLs at largest bank reached 75 percent. \\
\hline \multicolumn{3}{|l|}{ Mauritania } \\
\hline 1984-1993 & Systemic & $\begin{array}{l}\text { In } 1984,5 \text { major banks had non-performing assets ranging from } 45 \\
\text { percent to } 70 \text { percent of their portfolio. }\end{array}$ \\
\hline \multicolumn{3}{|l|}{ Mauritius } \\
\hline 1996 & Borderline & $\begin{array}{l}\text { The Central Bank closed two of } 12 \text { commercial banks for fraud and } \\
\text { other irregularities in } 1996 .\end{array}$ \\
\hline \multicolumn{3}{|l|}{ Mozambique } \\
\hline 1987-1995? & Systemic & $\begin{array}{l}\text { The country's principal bank experienced solvency problems that } \\
\text { became apparent after } 1992 \text {. }\end{array}$ \\
\hline \multicolumn{3}{|l|}{ Morocco } \\
\hline \multicolumn{3}{|l|}{ Niger } \\
\hline $1983-?$ & Systemic & $\begin{array}{l}\text { In the mid1980s, banking system NPLs reached } 50 \text { percent. Four } \\
\text { banks were liquidated and three restructured in the late } 1980 \text { s. }\end{array}$ \\
\hline
\end{tabular}




\begin{tabular}{|c|c|c|}
\hline $\begin{array}{l}\text { Country and } \\
\text { Dates }\end{array}$ & Scope of Crisis & Depth of Crisis \\
\hline \multicolumn{3}{|l|}{ Nigeria } \\
\hline $1990-1995$ & Systemic & $\begin{array}{l}\text { By 1993, insolvent banks account for } 20 \text { percent of total assets and } 22 \\
\text { percent of industry deposits; by 1995, almost half of the banks } \\
\text { reported to be in financial distress. }\end{array}$ \\
\hline 1997-? & Borderline & $\begin{array}{l}\text { Distressed banks accounted for } 3.9 \text { percent of banking system assets; } \\
26 \text { banks delicensed in } 1998 .\end{array}$ \\
\hline \multicolumn{3}{|l|}{ Rwanda } \\
\hline 1991-? & Borderline & One bank, with well-established branch network, closed. \\
\hline \multirow{2}{*}{\multicolumn{3}{|c|}{$\begin{array}{l}\text { Sao Tomé and } \\
\text { Principe }\end{array}$}} \\
\hline & & \\
\hline 1980s \& 1990s & Systemic & $\begin{array}{l}\text { At end1992, } 90 \text { percent of Monobank's loans were non-performing. } \\
\text { In } 1993 \text {, the commercial and development departments of the former } \\
\text { Monobank were liquidated, as was the only other financial institution. } \\
\text { At the same time, two new banks were licensed, which took over } \\
\text { many of the assets of their predecessors. The credit operations of one } \\
\text { newly created bank suspended at end } 1994 \text {. }\end{array}$ \\
\hline \multicolumn{3}{|r|}{ 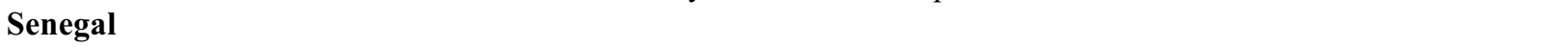 } \\
\hline $1988-1991$ & Systemic & $\begin{array}{l}\text { In } 1988,50 \text { percent of banking system loans were non-performing. } \\
\text { Six commercial banks and one development bank closed accounting } \\
\text { for roughly } 20-30 \text { percent of financial system assets. }\end{array}$ \\
\hline \multicolumn{3}{|l|}{ Sierra Leone } \\
\hline 1990-? & Systemic & $\begin{array}{l}\text { In } 1995,40-50 \text { percent of banking system loans were non-performing. } \\
\text { The license of one bank was suspended in } 1994 \text {. Recapitalization and } \\
\text { restructuring of banks is ongoing. }\end{array}$ \\
\hline \multicolumn{3}{|l|}{ Somalia } \\
\hline $1990 \mathrm{~s}$ & Borderline & $\begin{array}{l}\text { Claims on both private and public-sector borrowers were } \\
\text { nonperforming during the civil unrest. }\end{array}$ \\
\hline South Africa & & Banks could not service short-term foreign liabilities, government \\
\hline 1985 & Borderline & imposed moratorium on external capital payments. \\
\hline 1989-? & Borderline & $\begin{array}{l}\text { By end-1994, } 60 \text { to } 80 \text { percent of loans at state-owned banks were } \\
\text { nonperforming. }\end{array}$ \\
\hline \multicolumn{3}{|r|}{$T_{0}$} \\
\hline 1995 & Systemic & $\begin{array}{l}\text { Meridien BIAO Swaziland was taken over by the Central Bank. The } \\
\text { Central Bank also took over the Swaziland Development and Savings } \\
\text { Bank (SDSB), which faced severe portfolio problems. }\end{array}$ \\
\hline \multicolumn{3}{|l|}{ Tanzania } \\
\hline Late 1980s; 1990s & Systemic & $\begin{array}{l}\text { In 1987, the main financial institutions had arrears amounting to half } \\
\text { of their portfolio; The National Bank of Commerce with } 95 \text { percent of } \\
\text { industry assets became insolvent at least by } 1990-92 \text {. }\end{array}$ \\
\hline \multicolumn{3}{|l|}{ Togo } \\
\hline 1993-1995 & Systemic & \\
\hline \multicolumn{3}{|l|}{ Tunisia } \\
\hline 1991-1995 & Borderline & In 1991, most commercial banks undercapitalized. \\
\hline
\end{tabular}




\begin{tabular}{|lcc|}
\hline $\begin{array}{l}\text { Country and } \\
\text { Dates } \\
\text { Uganda }\end{array}$ & Scope of Crisis & \multicolumn{1}{c|}{ Depth of Crisis } \\
$1994-?$ & Systemic & 50 percent of banking system facing solvency problems. \\
$\begin{array}{l}\text { Zambia } \\
1995\end{array}$ & Systemic & $\begin{array}{l}\text { Meridien Bank with 13 percent of commercial bank assets became } \\
\text { insolvent. }\end{array}$ \\
$\begin{array}{l}\text { Zimbabwe } \\
1995-?\end{array}$ & Systemic & Commercial banks developed high NPLs. \\
\hline
\end{tabular}

Note: A crisis is defined as "systemic" if most or all of a country's banking-system capital is exhausted. In a "borderline" crisis, a severe erosion of capital is avoided by some of the country's major banks.

Seven African countries are not listed: Sudan; Comoros; Libya; Malawi; Namibia; Seychelles; and Western Sahara. For the last six of these, we were unable to locate data by which to establish independently that they had truly avoided crisis pressures.

Sources: Caprio and Klingebiel (1999), with additional information on Chad, South Africa, Somalia, and Zimbabwe and 1998 data on Nigeria taken from Lexis-Nexis. 


\begin{tabular}{|c|c|c|c|c|c|c|}
\hline \multicolumn{7}{|c|}{$\begin{array}{c}\text { Table 2 } \\
\text { Panel A } \\
\text { Background Information on Banking Sectors in Five African Countries from } 1995 \text { to June } 2000 \\
\end{array}$} \\
\hline Country & $\begin{array}{l}\text { Total } \\
\text { Number } \\
\text { of Banks }\end{array}$ & $\begin{array}{l}\text { No. of } \\
\text { Foreign } \\
\text { Banks }\end{array}$ & $\begin{array}{l}\text { No. of State- } \\
\text { Owned } \\
\text { Banks }\end{array}$ & Total Assets & $\begin{array}{l}\text { Deposit } \\
\text { Insurance } \\
\text { Scheme }\end{array}$ & $\begin{array}{ll}\text { Background Information } \\
\end{array}$ \\
\hline Kenya & 51 & $\begin{array}{c}9 \\
\text { (34.9\% of } \\
\text { market) }\end{array}$ & $\begin{array}{c}6 \\
\text { (24.7\% of } \\
\text { market) }\end{array}$ & $\$ 5.1$ billion & Explicit & $\begin{array}{l}\text { Liberalized sector } 20 \text { years ago. By the mid } 1980 \text { 's Kenya had one of the most } \\
\text { developed financial sectors in Africa. Liberal issuance of new bank charters, } \\
\text { however, caused rapid growth, outstripping the ability of the Central Bank to } \\
\text { supervise the banks. In 1986, three institutions failed and subsequent financial } \\
\text { sector reform proved largely unsuccessful. Currently, } 15 \text { banks control } 80 \% \text { of } \\
\text { industry's asset base and account for } 91 \% \text { of profits. }\end{array}$ \\
\hline Nigeria & 82 & $\begin{array}{l}15 \\
(27.1 \% \text { of } \\
\text { market })\end{array}$ & $\begin{array}{c}22 \\
(12.1 \% \text { of } \\
\text { market })\end{array}$ & $\$ 11.7$ billion & Explicit & $\begin{array}{l}\text { Nigeria's financial sector was largely controlled by the government from the } \\
1970 \text { 's through the early } 1990 \text { 's. In 1992, banks were included in a broad } \\
\text { privatization program, with } 14 \text { banks slated for privatization. } \\
\text { Broader financial-sector liberalization began in 1986. By 1991, inadequately } \\
\text { regulated financial institutions were showing signs of weakness. By } 1995 \text {, nearly } \\
\text { one half of licensed banks were distressed or insolvent. In 1996, the Nigerian } \\
\text { government gave banks until March } 1997 \text { to recapitalize (there were } 115 \\
\text { commercial banks). Banks not meeting recapitalization requirements were } \\
\text { subsequently closed. In } 1998,26 \text { banks were liquidated, and in } 1999 \text { another } 7 \\
\text { were liquidated. Less than half of the surviving banks were competitive. } \\
\text { Currently, } 3 \text { banks control } 40 \% \text { of industry's asset base. } 7 \text { merchant banks also } \\
\text { exist. }\end{array}$ \\
\hline Uganda & 14 & 5 & 2 & $\begin{array}{l}\$ 1.98 \\
\text { million }\end{array}$ & Explicit & $\begin{array}{l}\text { In the late } 1980 \text { 's and early } 1990 \text { 's two large government-owned banks were } \\
\text { deemed insolvent. One of two public banks, UCB accounts for } 39 \% \text { of total } \\
\text { deposits. The banks were not closed, but attempts have been made to recapitalize } \\
\text { and sell these institutions. The government also intervened in two private } \\
\text { domestic banks in } 1995 \text {. } 65 \% \text { of industry assets are in top three banks. In early } \\
1999 \text {, the Bank of Uganda raised capital requirements and implemented reforms to } \\
\text { reduce fraud. }\end{array}$ \\
\hline Zambia & 15 & NA & 7 & $\$ 652$ million & Implicit & Liberalized banking sector in 1992. \\
\hline Zimbabwe & 19 & 6 & 2 & $\$ 1.9$ billion & Implicit & $\begin{array}{l}\text { Liberalized banking sector in 1991. Currently, as a result of the collapse of the } \\
\text { large United Merchant Bank, all but } 5 \text { banks are struggling, in part due to } \\
\text { exposure to UMB in excess of } \$ 2 \text { billion (See Panel B). Three additional banks } \\
\text { were reported near collapse in Oct. } 1998 \text {. }\end{array}$ \\
\hline
\end{tabular}




\begin{tabular}{|c|c|c|c|c|}
\hline \multicolumn{5}{|c|}{$\begin{array}{c}\text { Table 2 } \\
\text { Panel B } \\
\text { A Partial List of Commercial Bank Failures in Selected African Countries from } 1995 \text { to June } 2000\end{array}$} \\
\hline Country & Bank Name & $\begin{array}{l}\text { Date of } \\
\text { Failure }\end{array}$ & Comments & Action-Forcing Triggers \\
\hline \multirow[t]{9}{*}{ Kenya } & Diners Finance Ltd. & $1994-5$ & Liquidated. & \\
\hline & $\begin{array}{l}\text { Central Finance Ltd. } \\
\text { Meridian Bank }\end{array}$ & $\begin{array}{l}\text { 1994-5 } \\
\text { Apr. } 96\end{array}$ & $\begin{array}{l}\text { Liquidated. } \\
\text { Headquartered in Cayman Islands. A } \\
\text { very significant failure. Branches } \\
\text { liquidated in other African countries. }\end{array}$ & $\begin{array}{l}\text { Meridian began by aggressively mobilizing deposits, then absconded } \\
\text { with deposits. }\end{array}$ \\
\hline & Kenya Finance Bank & Jul. 96 & $\begin{array}{l}\text { Placed under Central Bank } \\
\text { management in July } 1996 \text {. Efforts to } \\
\text { revive the bank failed and it was } \\
\text { liquidated. }\end{array}$ & Liquidity problem. \\
\hline & Heritage Bank & Oct. 96 & & \\
\hline & Ari Bank & Sep. 97 & & $\begin{array}{l}\text { Liquidity and managerial problems. Central Bank reportedly } \\
\text { recognized bank's weakness earlier, but was slow to react. }\end{array}$ \\
\hline & Reliance Bank & Sep. 7, 98 & & Issued checks not backed by deposits. \\
\hline & Trust Bank of Kenya & Sep. 17,98 & $\begin{array}{l}\text { Kenya's } 6^{\text {th }} \text {-largest bank, with branches } \\
\text { in Tanzania and Uganda. Run ensued } \\
\text { in September } 1998 \text { following reports of } \\
\text { financial mismanagement. }\end{array}$ & Insufficient funds to meet depositor run. \\
\hline & Bullion Bank & Aug. 98 & $\begin{array}{l}\text { Under statutory management by } \\
\text { Central Bank. }\end{array}$ & \\
\hline & Prudential Bank & Sep. 98 & $\begin{array}{l}\text { Under statutory management by } \\
\text { Central Bank. }\end{array}$ & \\
\hline \multirow[t]{7}{*}{ Nigeria } & $\begin{array}{l}\text { ( } 26 \text { Banks in total - } \\
\text { Some bank names not } \\
\text { found.) }\end{array}$ & Jan. 98 & & Liquidated due to years of mismanagement and fraud. \\
\hline & United Commercial Bank & 1994-5 & & In Liquidation. \\
\hline & African Continental Bank & $1994-5$ & & Taken over by the Nigerian Deposit Insurance Corporation (NDIC). \\
\hline & National Bank of Nigeria & $1994-5$ & & Taken over by the NDIC. \\
\hline & New Nigeria Bank, Ltd. & $1994-5$ & & Taken over by the NDIC. \\
\hline & Pan African Bank Ltd. & $1994-5$ & & Taken over by the NDIC. \\
\hline & $\begin{array}{l}\text { Cooperative and } \\
\text { Commerce Bank Plc }\end{array}$ & $1994-5$ & & Taken over by the NDIC. \\
\hline
\end{tabular}


TABLE 3

AVAILABLE ESTIMATES OF THE DIRECT COSTS OF RESTRUCTURING AND RECAPITALIZING BANKS IN AFRICAN COUNTRIES

\begin{tabular}{|ccc|}
\hline Country & Dates & $\begin{array}{c}\text { Reported Costs of Insolvency } \\
\text { Resolution }\end{array}$ \\
Benin & $1988-1990$ & 17 percent of GDP \\
Botswana & $1994-1995$ & 0.6 percent of GDP \\
Côte d'Ivoire & $1988-1991$ & 25 percent of GDP \\
Ghana & $1982-1989$ & 6 percent of GDP \\
Guinea & 1985 & 3 percent of GDP \\
Mauritania & $1984-1993$ & 15 percent of GDP \\
Senegal & $1988-1991$ & 17 percent of GDP \\
Tanzania & $1980 \mathrm{~s}$ & Nearly 10 percent of GDP \\
Tunisia & $1991-1995$ & 3 percent (raised as equity by banks) \\
Zambia & 1995 & 1.4 percent of GDP \\
\hline
\end{tabular}

Source: Caprio and Klingebiel (1999). 


\section{TABLE 4 SIX STAGES OF A FINANCIAL CRISIS}

- Stage 1: Generation of Multiple Zombie Institutions through Corrupt, Imprudent, or Government-Directed Lending

- In the Short Run, Losses from Bank Participation in Subsidized Lending are Offset by Subsidies to Risk Taking

- Stage 2: Escalating Silent Runs Test the Strength of Government Commitment to Support Zombies

- Bank and Government Reliance on Disinformation and Coverup

- Difficulty of Averting an Open Run Grows as Zombieness Spreads and Deepens Over Time

- Stage 3: A Systemic Crisis Ensues when the Bureaucratic Structure for Supporting Guarantees Loses Credibility

- Stage 4: Recapitalization or Creation of Government Stabilization Fund of Government Reserves

4A. One or more Stopgap Partial Recapitalizations: Return the System Temporarily to Stage 1 or 2

4B. Full Taxpayer Bailout or Explicit Nationalization of Zombie Banks

- Stage 5: Full Clean-Up of Zombie Institutions

- Stage 6: Macro and Banking Policy Reforms, Accompanied by a Political Distribution of Blame for Costs Imposed on Taxpayers 


\section{TABLE 5}

\section{DIALECTICAL VIEW OF ECONOMIC CRISES}

THESIS: Unsustainable Policy Mix

- Expansion of Value-Sabotaged Loans from Credit-Allocation Scheme vs. Credibility of Government Guarantees of Bank Liabilities

- Incremental Deficits Implied by Expanding Guarantees vs. Relatively Fixed Exchange Rates

ANTITHESIS: Market Discipline Tests Government's Ability to Fulfill its Increasingly Expensive Promises to Support Exchange Rate or Banking System

- In Currency Crises, Test $=$ Bear Raids

- In Banking Crises, Test $=$ Silent Runs (Symptoms)

SYNTHESIS: Crisis Occurs when Authorities' Ability to Shift Losses to Taxpayers Loses Credibility and the Threat of Bear Raids and Runs Forces them to Accept the Need to Change Policy Mix $=$ New Thesis

- Unsustainable Distribution Effects in Interim Policy Mix are Dictated by Conditions Attached to IMF Loans

- Political Economy of Bailouts, Recapitalizations, and Blame Can Easily Lock a Country's Banking System in Distress Mode 
TABLE 6

1999 VALUES OF CORUPTION PERCEPTION IDENX, PRESS RESTRAINT INDEX, AND REAL GDP PER CAPITA IN SELECTED COUNTRIES

\begin{tabular}{|c|c|c|c|c|c|}
\hline $\begin{array}{c}\text { Rank in } \\
\text { TICPI } \\
\text { Dataset }\end{array}$ & Country & $\begin{array}{l}1999 \text { CPI } \\
\text { Score }\end{array}$ & $\begin{array}{c}\text { Press } \\
\text { Restraint } \\
\text { (PR) }\end{array}$ & $\begin{array}{c}\text { GDP p.c. } \\
\text { (PPP\$) } \\
\text { (GDP) } \\
\end{array}$ & $\begin{array}{c}\begin{array}{c}\text { Total years in } \\
\text { crisis }\end{array} \\
(\mathrm{Y}) \\
\end{array}$ \\
\hline 1 & Denmark & 10 & 0.9 & 23,690 & \\
\hline 2 & Finland & 9.8 & 1.5 & 20,150 & \\
\hline 3 & New Zealand & 9.4 & 0.8 & 17,410 & \\
\hline 3 & Sweden & 9.4 & 1 & 19,790 & \\
\hline 5 & Canada & 9.2 & 1.6 & 22,480 & \\
\hline 5 & Iceland & 9.2 & 1.2 & 22,497 & \\
\hline 13 & United Kingdom & 8.6 & 2 & 20,730 & \\
\hline 18 & USA & 7.5 & 1.3 & 29,010 & \\
\hline & & & & & \\
\hline 24 & Botswana & 6.1 & 3 & 7,690 & 2 \\
\hline 29 & Namibia & 5.3 & 3.8 & 5,010 & NA \\
\hline 34 & South Africa & 5 & 2.8 & 7,380 & 12 \\
\hline 34 & Tunisia & 5 & 7.4 & 5,300 & 5 \\
\hline 36 & Mauritius & 4.9 & 2 & 9,310 & 10 \\
\hline 45 & Malawi & 4.1 & 4.2 & 710 & NA \\
\hline 45 & Morocco & 4.1 & 5.1 & 3,310 & 4 \\
\hline 45 & Zimbabwe & 4.1 & 6.4 & 960 & 5 \\
\hline 56 & Mozambique & 3.5 & 4.8 & 740 & 9 \\
\hline 56 & Zambia & 3.5 & 6.2 & 960 & 1 \\
\hline 58 & Senegal & 3.4 & 3.3 & 1,730 & 4 \\
\hline 63 & Egypt & 3.3 & 6.9 & 3,050 & 9 \\
\hline 63 & Ghana & 3.3 & 6.1 & 1,640 & 11 \\
\hline 75 & Ivory Coast & 2.6 & 7.4 & 1,840 & 4 \\
\hline 87 & Uganda & 2.2 & 4 & 1,160 & 6 \\
\hline 90 & Kenya & 2 & 7 & 1,190 & 12 \\
\hline 90 & Tanzania & 1.9 & 5.1 & 580 & 13 \\
\hline & & & & & \\
\hline 96 & Azerbaijan & 1.7 & 7.3 & 1,550 & \\
\hline 96 & Indonesia & 1.7 & 5.3 & 3,490 & \\
\hline 98 & Nigeria & 1.6 & 5.5 & 920 & 9 \\
\hline 99 & Cameroon & 1.5 & 7.7 & 1,890 & 11 \\
\hline
\end{tabular}

Note: The Table includes all African countries in Transparency International's 99-country dataset. Other countries with either very high or very low TICPI are included as benchmarks.

Sources: CPI Score: Transparency International Corruption Index (TICPI), archived at the University of Göttingen's Internet Center for Corruption Research (www.transparency.de);

PR: 1999 Freedom House Index of the extent of governmental pressures and influence on news content, rescaled by dividing by 10 to increase comparability with TIPCI (www.freedomhouse.org);

GDP: 1999 Freedom House presentation of dollar value of real GDP per capita;

Y: Total years in crisis as shown in Table 1 (for African countries only). 
TABLE 7

REGRESSION TESTS OF THE INCENTIVE-CONFLICT HYPOTHESIS IN AFRICAN COUNTRIES

$$
\mathrm{Y}=\mathrm{a}+\mathrm{b}_{1} \mathrm{C}\left(+\mathrm{b}_{2} \mathrm{PR}+\mathrm{b}_{3} \mathrm{GDP}\right)+\mathrm{u}
$$

\begin{tabular}{|c|c|c|c|c|}
\hline Regressor & $\begin{array}{l}\text { Square of Bivariate } \\
\text { Correlation with Y }\end{array}$ & Model 1 & Model 2 & Model 3 \\
\hline $\mathrm{C}$ & $\begin{array}{r}.297 * * \\
(\mathrm{t}=2.52)\end{array}$ & $\begin{array}{c}1.372^{*} \\
(\mathrm{t}=1.82)\end{array}$ & $\begin{array}{c}1.373^{*} \\
(\mathrm{t}=2.13)\end{array}$ & $\begin{array}{c}1.358 \\
(\mathrm{t}=1.73)\end{array}$ \\
\hline PR & $\begin{array}{c}.073 \dagger \\
(\mathrm{t}=1.09)\end{array}$ & $\ldots$ & $\begin{array}{c}.120 \\
(\mathrm{t}=.22)\end{array}$ & $\begin{array}{c}.111 \\
(\mathrm{t}=.17)\end{array}$ \\
\hline GDP & $\begin{array}{c}.061 \\
(\mathrm{t}=1.65)\end{array}$ & $\begin{array}{c}-.0001 \\
(\mathrm{t}=-.12)\end{array}$ & $\ldots$ & $\begin{array}{l}<-.0001 \\
(\mathrm{t}=-.04)\end{array}$ \\
\hline Intercept a & .. & $\begin{array}{c}2.350 \\
(t=.64)\end{array}$ & $\begin{array}{c}1.552 \\
(\mathrm{t}=.52)\end{array}$ & $\begin{array}{c}1.702 \\
(\mathrm{t}=.32)\end{array}$ \\
\hline $\mathrm{R}^{2}$ & $\ldots$ & .298 & .299 & .300 \\
\hline $\mathrm{N}$ & 17 & 17 & 17 & 17 \\
\hline
\end{tabular}

Y: Number of years spent in crisis between 1980 and 1999

C: TICPI divided by 10

PR: $\quad$ Freedom House Index of Press Restrictions rescaled by dividing by 10

GDP: Real Per Capita Gross Domestic Product

* Significant at the $10 \%$ level

** Significant at the $5 \%$ level

$\dagger \quad \mathrm{PR}$ is available for 47 of the African countries with readings on $\mathrm{Y}$. The $\mathrm{R}^{2}$ in this larger sample is .024 and the t-statistic is 1.05 , indicating that selecting on the availability of TICPI did not greatly bias our results. 
FIGURE 1A

BANKING PROBLEMS AND CRISES IN AFRICA 1980-1999

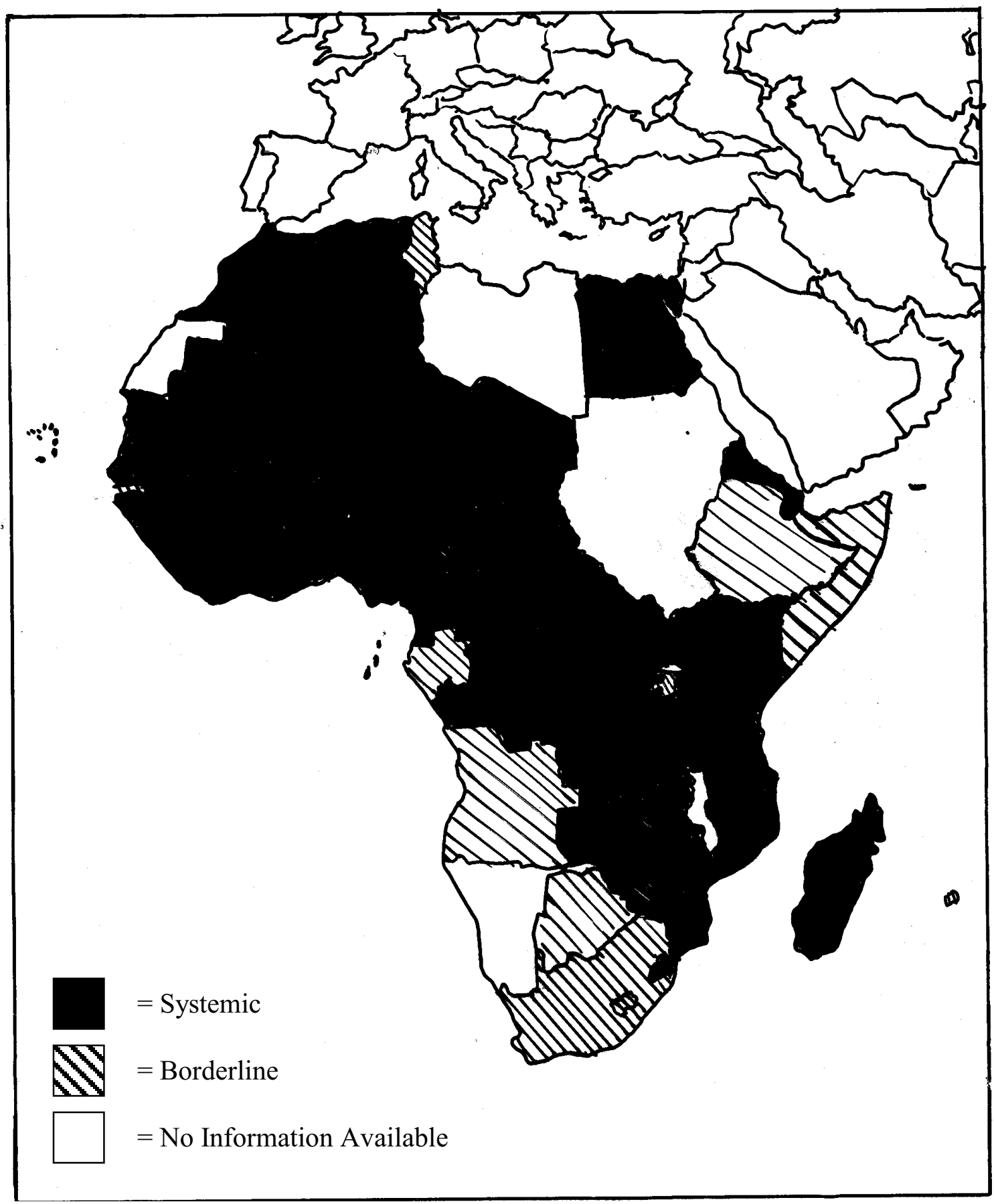

Sources: Lindgren, Garcia, and Saal (1996) and Caprio and Klingebiel (1996b). 
RECURRENT BANKING PROBLEMS AND CRISES 1980-1999

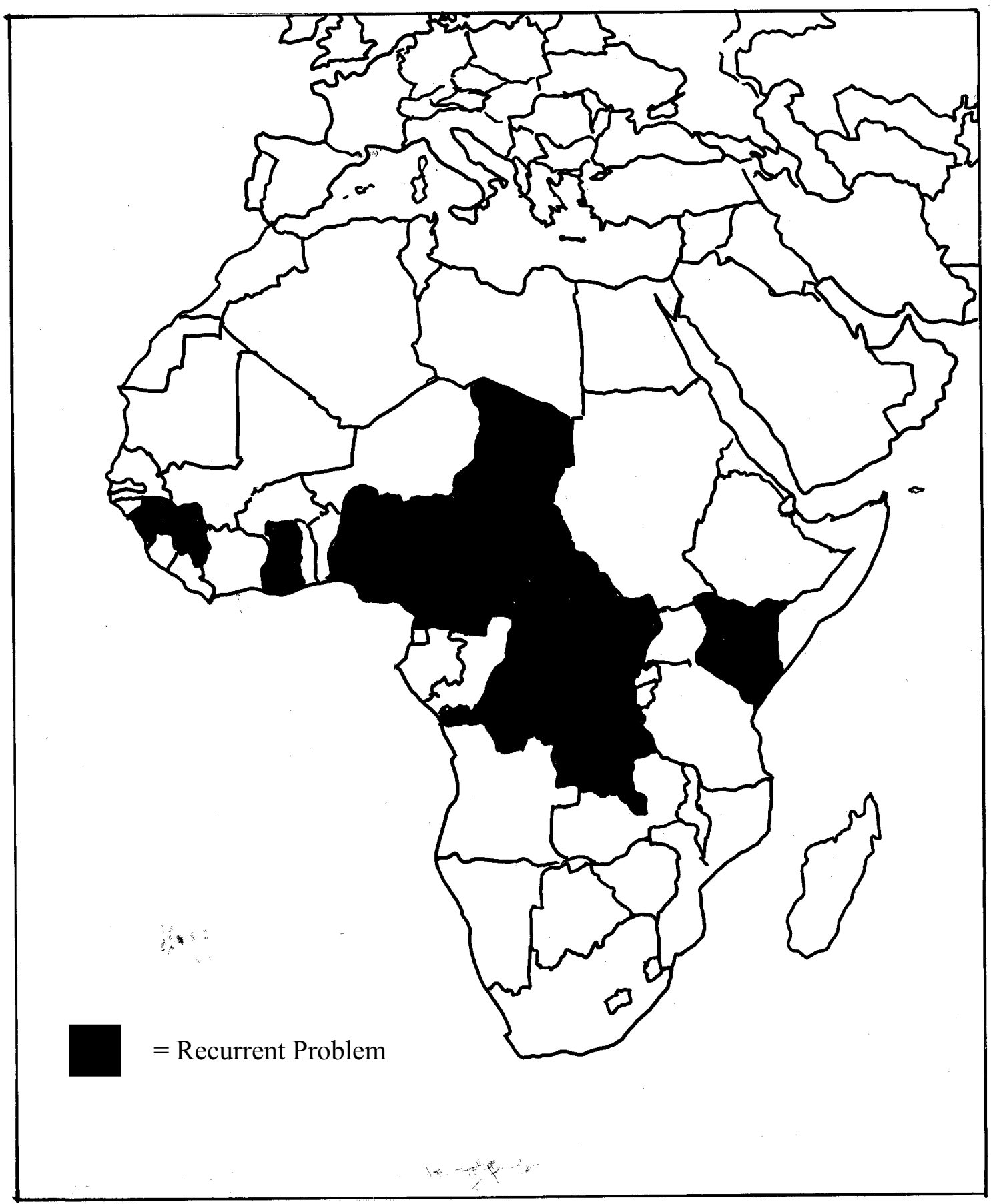

Sources: Lindgren, Garcia, and Saal (1996) and Caprio and Klingebiel (1996b). 

Figure 2

Number of Countries in Africa Experiencing Banking Crises from 1980 to 1999

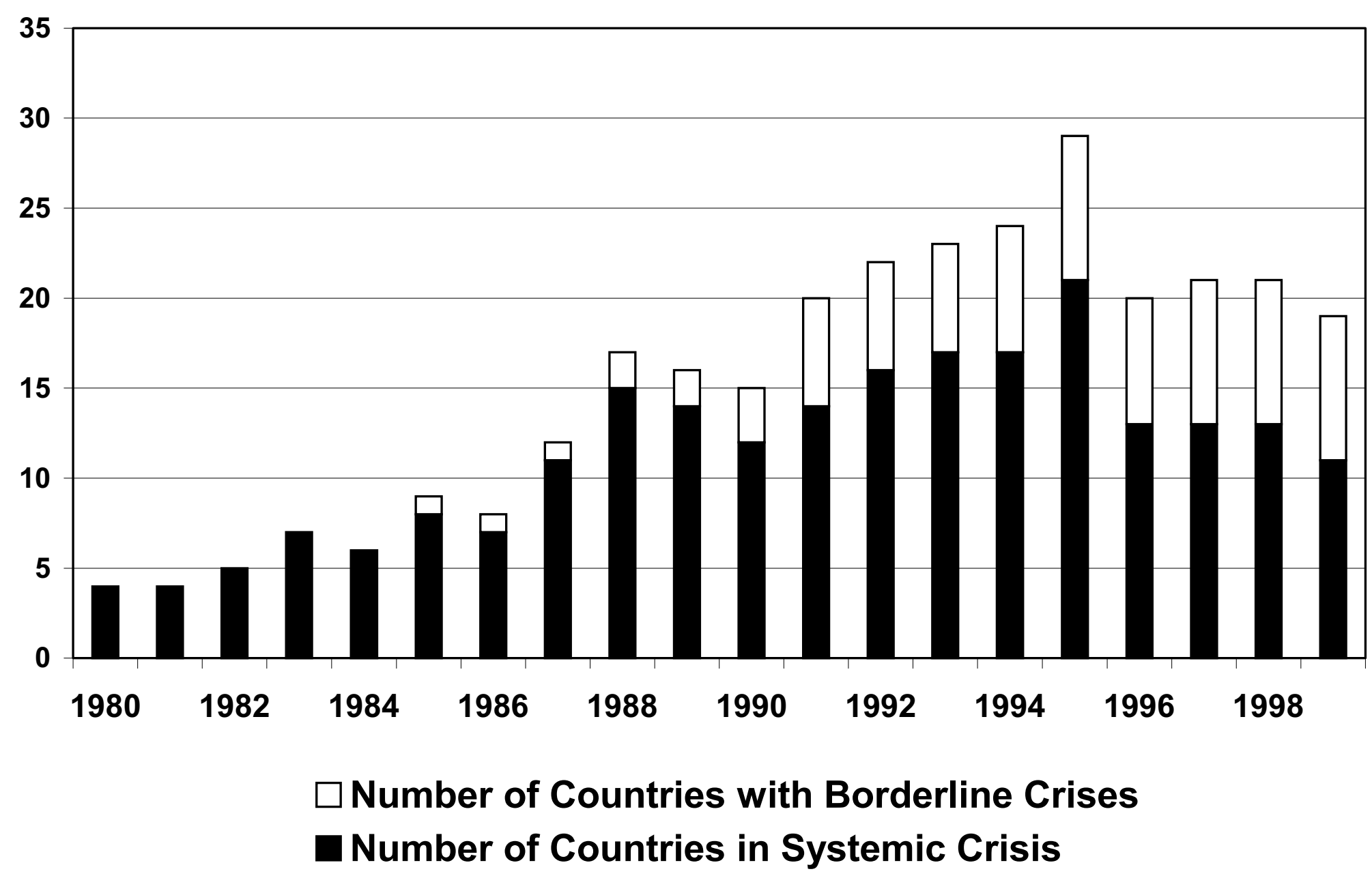


Figure 3

Total Number of Years of Systemic and Borderline Crises

in Selected Africa Countries from 1980 to 1999

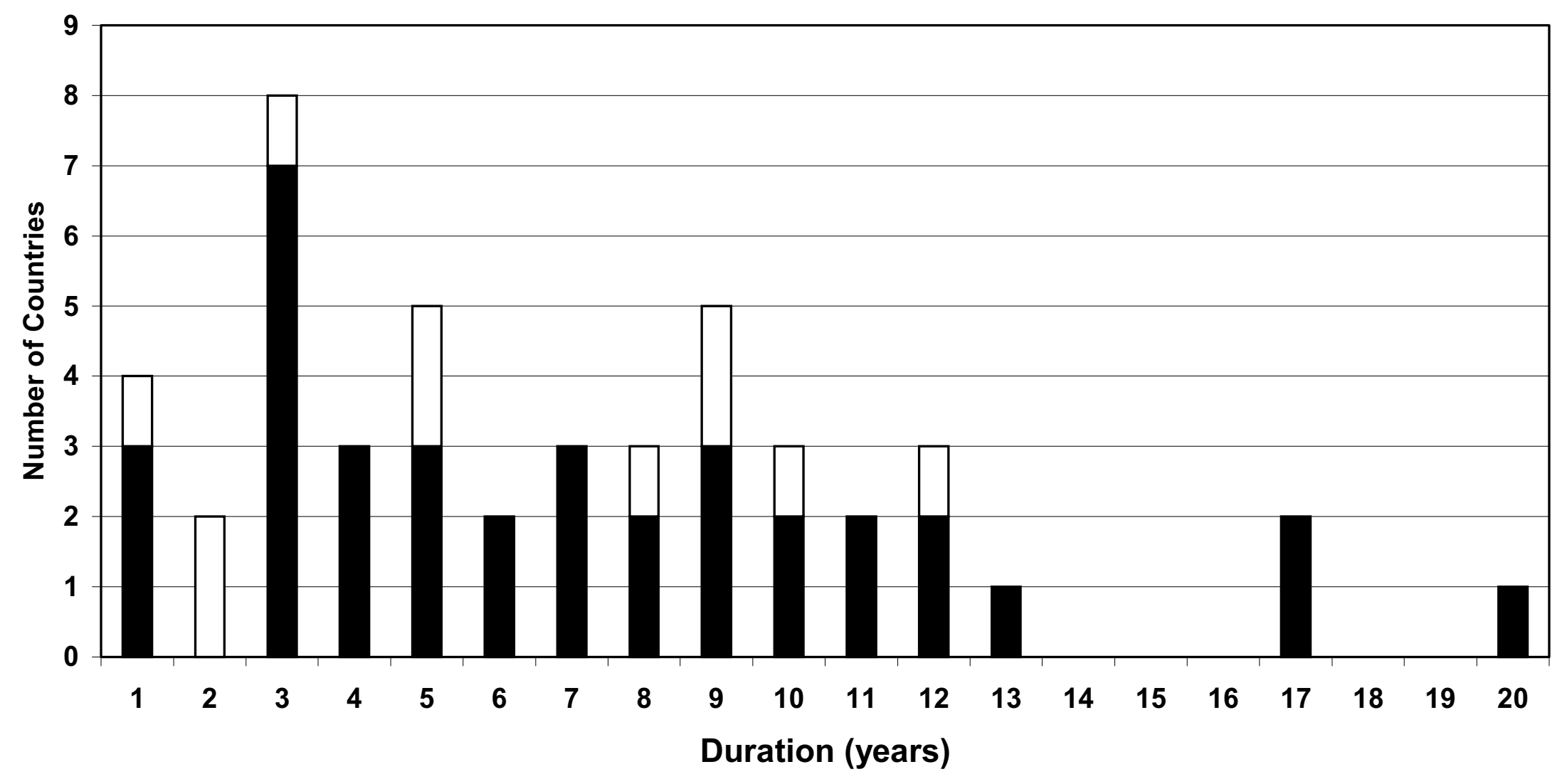

- Systemic Crises $\square$ Borderline Crises

Sources: Lindgren, Garcia and Saal (1996); Caprio and Klingebiel (1999) 
Figure 4

Non-Performing Loans (NPL) to Total Loans as Reported by 40 Kenyan Banks, 1995-1997

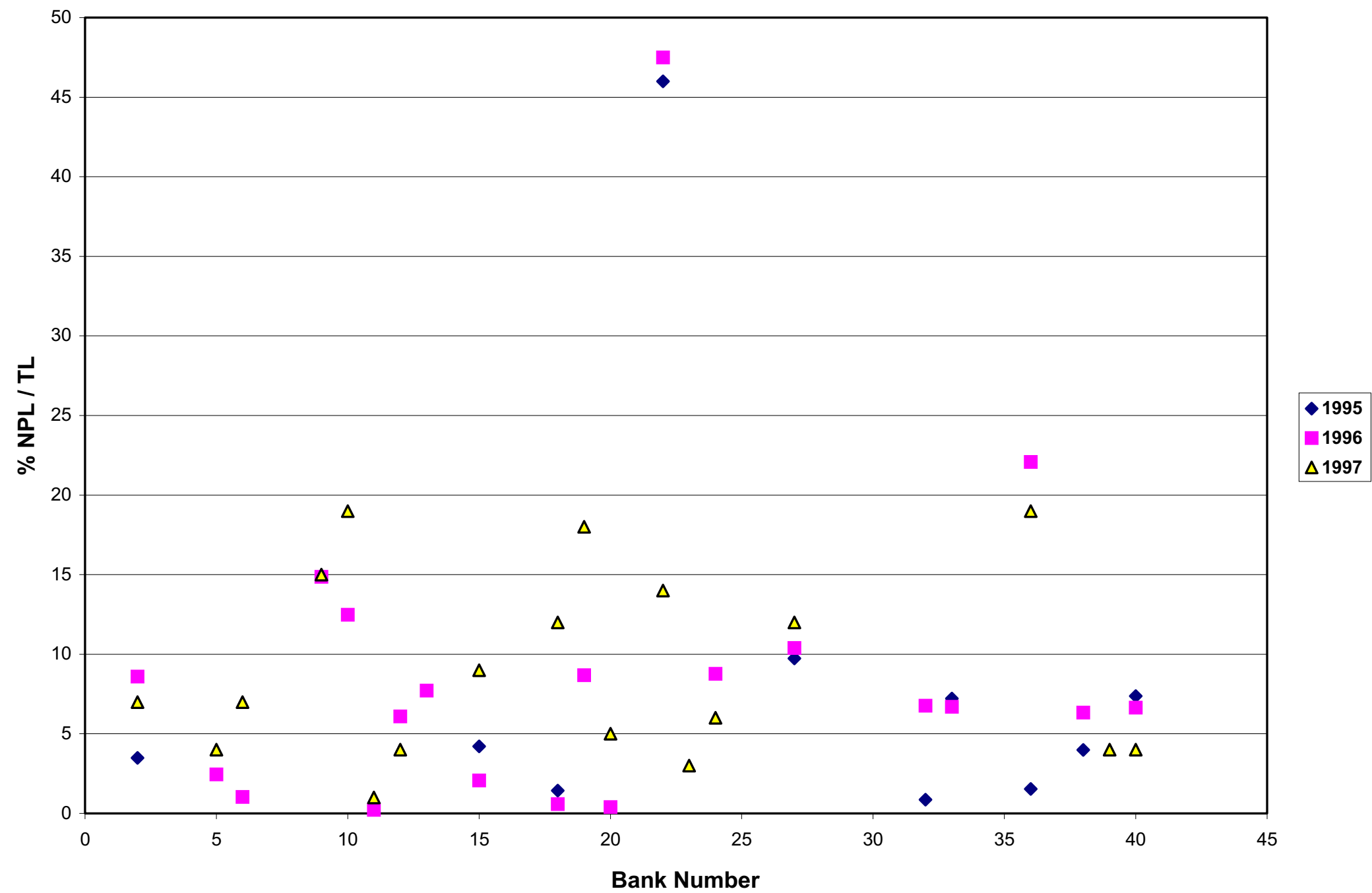

Source: OCC using data from FitchIBCA Bankscope. 